\title{
Behavior of Circular Glass Fiber Reinforced Polymer Tubes Under Axial Compression
}

\author{
Yazhini A \\ Mepco Schlenk Engineering College \\ Sivakasi - 626005 , \\ Tamilnadu, India
}

\author{
Ramesh Babu C \\ Mepco Schlenk Engineering College \\ Sivakasi - 626005 \\ Tamilnadu, India
}

\begin{abstract}
This project involves an evaluation of behaviour of circular GFRP tubes under axial compression. Circular tube columns having different length and cross sections resulting in the range of combinations of global and sectional slenderness, were tested under axial load. From this study, the compressive strength, ultimate load and failure modes were determined. After experimental investigation on evaluation of behavior of GFRP tubes, numerical investigation process is started, using ANSYS. Finite element models of the circular tubes will be generated and analyzed using SHELL elements. In this process orthotropic properties has been defined to align the material direction of the composite lay-up and stacking sequence. The experimental results were compared with the analytical results. It includes the parametric study of $\mathrm{L} / \mathrm{D}$ and $\mathrm{D} / \mathrm{t}$ ratio of various dimensions and orientation in finite element model. It gives the best orientation angle for the compressive behavior of GFRP tubes
\end{abstract}

Keywords: Circular Glass Fiber Reinforced Polymer (GFRP), Compressive, shell, Fiber orientation

\section{INTRODUCTION}

\subsection{Fiber Reinforced Polymer}

In recent years, fiber reinforced polymer (FRP) have been used as an alternative for traditional materials. It have found increasingly wide applications in civil engineering, both in the new construction and in retro fit of existing structures. Fiber Reinforced Polymer composites possess several advantages over steel, due to high strength-to-weight ratio and good corrosion resistance. For the retrofit of structures, Fiber reinforced polymer has been used as an externally bonded reinforcement has become very popular in recent years. [1] In reinforced concrete column retrofit, FRP is primarily used as an external jacket to provide confinement to the concrete core . Confinement also enhances the compressive load capacity of a concrete filled FRP tube column, and reduces the required column cross-section compared to that of a conventional RC column [3]. In the last 20 years, various authors have addressed the performance and strength of pultruded GFRP members subject to concentric compression. Daniel C.T. Cardoso [5] derived the compressive strength equation for square GFRP tubes. The buckling behavior and interaction between crushing local and global buckling was observed. Jeffrey Richard Mitchell [8] have studied optimal partial concrete filling of frp and effect of $\mathrm{d} / \mathrm{t}$ ratios for different laminates. The relationship between optimal partial concrete filling of frp and $\mathrm{d} / \mathrm{t}$ ratio observed was linear.

\subsection{Types of fibers}

The classification of FRP composites is based on the types of fibers used as the reinforcement .There are three types of fibers dominating civil engineering industry: Glass, carbon and aramid fibers. Among these fibers Glass fibers plays a predominant role.

\subsection{Glass Fiber Reinforced polymer}

Glass fibers are a processed form of glass, which is composed of a number of oxides (mostly silica oxide), together with other raw materials (such as limestone, fluorspar, boric acid, clay). They are manufactured by drawing those melted oxides into filaments ranging from 3 $\mathrm{mm}$ to $24 \mathrm{~mm}$. There are five forms of glass fibres used as the reinforcement of the matrix material: chopped fibres, chopped strands, chopped strandmats, woven fabrics, and surface tissue.

Glass fiber reinforced polymer (GFRP) have gained acceptance among civil engineers due to their advantages over traditional construction materials: high strength to weight ratio and superior corrosion resistance, for instance. Additionally, large scale pultrusion of GFRP has contributed to reducing manufacturing costs, making these products competitive. Significant efforts are underway worldwide to develop standard provisions for the design of GFRP structural members. [2].

\subsection{Member and section classification}

Columns are conventionally classified as being short, intermediate or long based on their relative column slenderness ratio. Depending upon slenderness ratio the column generally fail by either local or global buckling.

\section{EXPERIMENTAL PROGRAM}

GFRP hollow tubes of various cross sections having different lengths and diameter were tested.12 specimens were taken from 4 different batches of GFRP tubes. After arrangement on compressive testing machine the GFRP tubes were applied axial load. Axially compressive tests were processed to obtain material properties and compressive strength.

Table1. Specimen Specification

\begin{tabular}{|c|c|c|c|c|c|}
\hline $\begin{array}{c}\text { Diameter } \\
\text { mm }\end{array}$ & $\begin{array}{c}\text { No of } \\
\text { specimen }\end{array}$ & $\begin{array}{c}\text { Length } \\
\mathbf{m m}\end{array}$ & $\begin{array}{c}\text { Thickness } \\
\mathbf{m m}\end{array}$ & $\begin{array}{c}\text { D/t } \\
\text { ratio }\end{array}$ & $\begin{array}{c}\text { L/D } \\
\text { ratio }\end{array}$ \\
\hline 320 & 3 & 579 & 5 & 64 & 1.8 \\
\hline 325 & 3 & 653 & 7.5 & 43.3 & 2 \\
\hline 164 & 3 & 338 & 3 & 54.6 & 3 \\
\hline 310 & 3 & 1200 & 5 & 62 & 3.8 \\
\hline
\end{tabular}




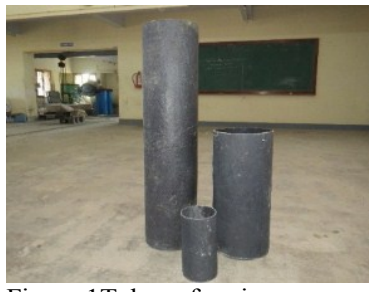

Figure 1Tubes of various cross Section

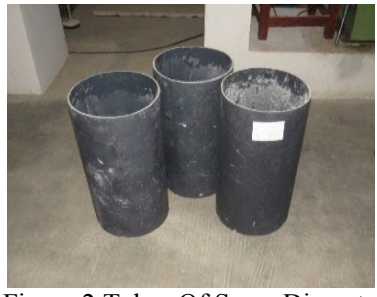

Figure 2 Tubes Of Same Diameter $320 \mathrm{~mm}$

\subsection{Experimental Set-Up}

\subsubsection{Short GFRP tube}

In the compressive testing machine the hollow circular GFRP tubes were fixed by using base plates. Axial load is applied at the top of the plate and the load is transformed in the form of udl to the tube. On reaching the particular load, the tube crushed at the bottom producing a longitudinal crack with a large sound. The critical load at which the tube is crushed is obtained and the tube with an increased thickness has obtained more load value. The stress strain values are noted.

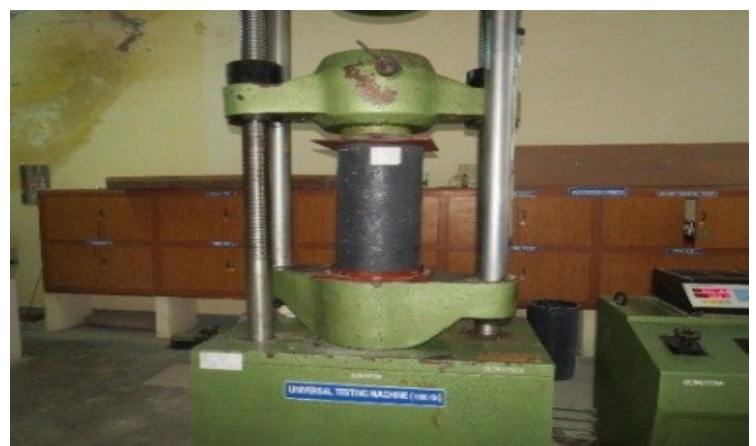

Figure 3. Experimental set-up for short tube

\subsubsection{Long GFRP tube}

The tube with the increased length is tested in the column testing frame. The bottom is fixed and at the top the axial load is applied in the form of udl through the base plates. The load is applied from the loading jack. The demec gauges are used to obtain the strain values. The experimental set up is shown in the figure 4.

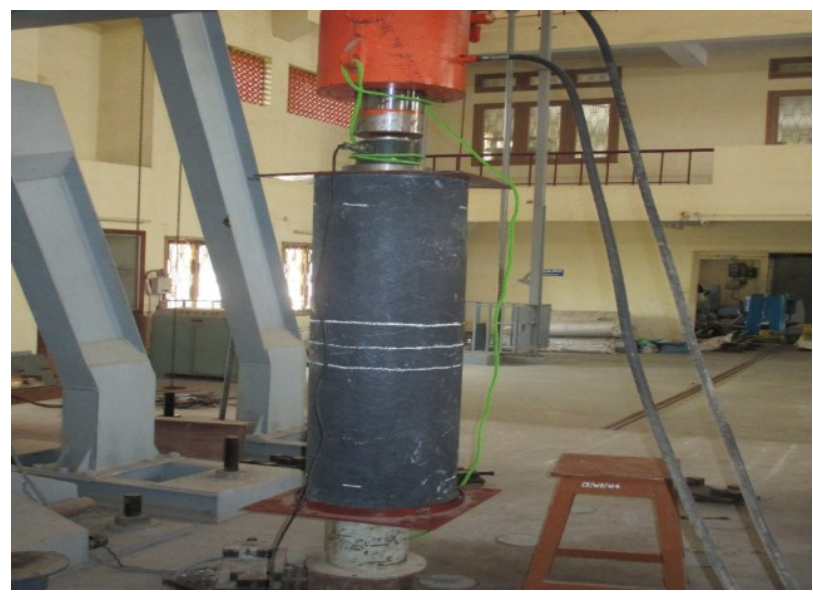

Figure 4. Experimental set-up for Long tube

\subsubsection{Crushed GFRP tube}

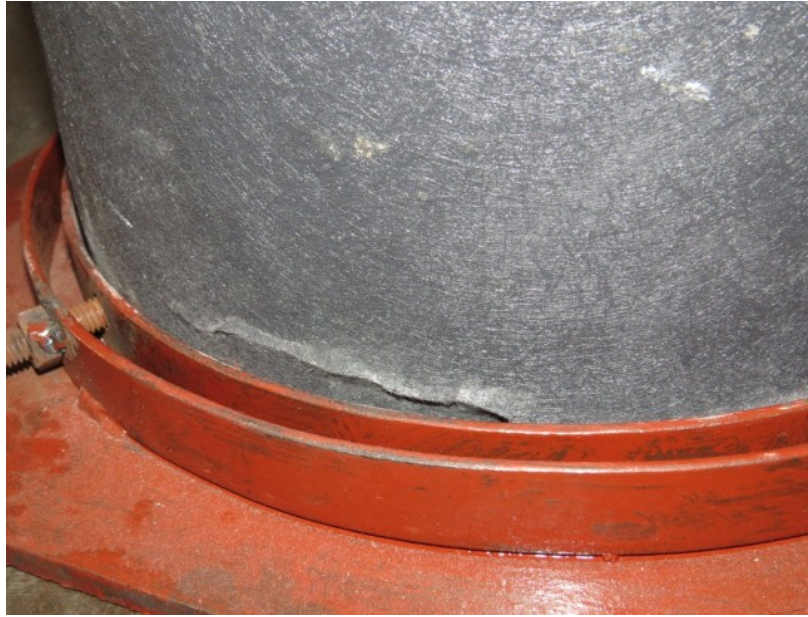

Figure 5. Crushed at the bottom

On applying the load, the GFRP tube buckle with a longitudinal crack at the bottom. The original length has been changed. The deformed length is taken. The load vs displacement, stress vs strain curves have been obtained. The average load value is taken for the circular GFRP tubes.For the specimen $1,2,3$ the obtained load value is $312 \mathrm{kN}, 336$ $\mathrm{kN}, 124 \mathrm{kN}, 105.6 \mathrm{kN}$.

\section{FINITE ELEMENT ANALYSIS 3.1 Application of ANSYS - FEA}

Numerical methods provide a general device to study arbitrary geometries and loading conditions. Among them Finite Element Analysis has been broadly used in which it requires more set of data to obtain precise results. Structural analysis is one of the application of Finite Element Model .

Two Different types of structural analysis are used.

- Static Analysis

- Buckling Analysis

\subsection{Overview of analysis}

This method is used to find the buckling load at which the structure becomes unstable. It includes the following steps.

- Erect the model

- Establish the static solution

- Attain the eigen value buckling solution

- Develop the solution

-Analyse the results

\subsection{Elements used in ansys}

In Ansys different types of elements are used depending on the problem nature and the type of analysis to be performed. Here shell elements have been used. For layered elements and different orientation shell 281 element is used .It is a 8-node structural solid element designed to model layered thick shells. For this key options, under storage of layer data all layers + middle data should be entered. For this orientation we should specify the following conditions.

- Individual layer properties should be defined.

- Define the number of layers.

- State the material properties.

- Assign layer orientation angle and thickness.

- Analyse the model. 


\subsection{Material properties}

For GFRP tubes the following properties are used

Table 2 .Material Properties

\begin{tabular}{|l|l|}
\hline \multicolumn{2}{|c|}{ Properties of GFRP } \\
\hline $\mathrm{Ex}, \mathrm{GPa}$ & 40.2 \\
\hline $\mathrm{Ey}, \mathrm{GPa}$ & 6.2 \\
\hline $\mathrm{Ez}, \mathrm{GPa}$ & 40 \\
\hline$\mu x y$ & 0.2 \\
\hline$\mu \mathrm{xz}$ & 0.2 \\
\hline$\mu \mathrm{yz}$ & 0.2 \\
\hline $\mathrm{Gxy}, \mathrm{GPa}$ & 3.0 \\
\hline $\mathrm{Gxz}, \mathrm{GPa}$ & 2.3 \\
\hline Gyz, GPa & 1.51 \\
\hline Density, $\mathrm{Kg} / \mathrm{m}^{3}$ & 1910 \\
\hline
\end{tabular}

\section{4 .RESULTS AND DISCUSSION}

For gfrp tube of external diameter $320 \mathrm{~mm}$ and thickness $5 \mathrm{~mm}$, the buckling load is obtained by using shell 41 membrane element by eigen buckling method.

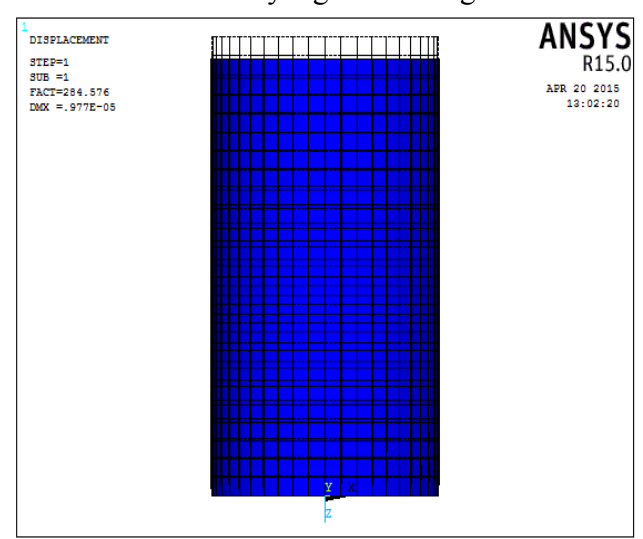

Figure 6. Deformed + Un deformed for Diameter $320 \mathrm{~mm}$

Similarly for the GFRP tube of external diameter $310 \mathrm{~mm}$ and an internal diameter of $300 \mathrm{~mm}$ with a thickness of $5 \mathrm{~mm}$ is analysed in Ansys by Eigen value buckling method and the buckling load is obtained

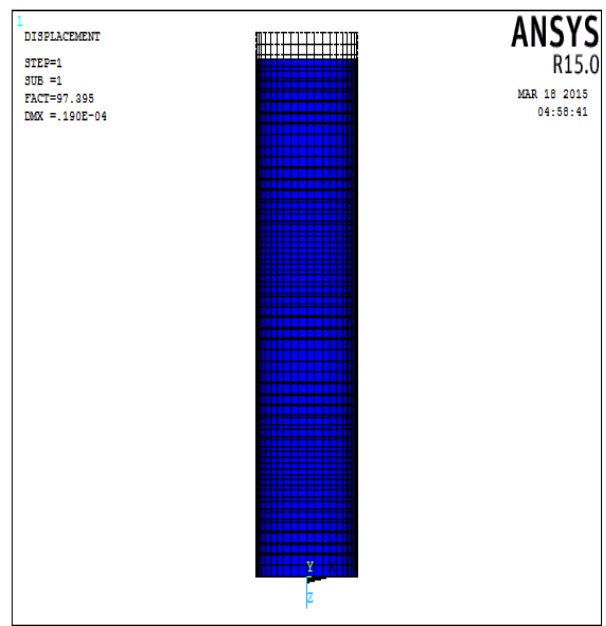

Figure 7. Deformed + Un deformed for diameter $310 \mathrm{~mm}$
Table 3. Load calculation

\begin{tabular}{|l|l|l|l|l|}
\hline SNe & $\begin{array}{l}\text { Diameter } \\
\text { mm }\end{array}$ & $\begin{array}{l}\text { Length } \\
\text { mm }\end{array}$ & $\begin{array}{l}\text { Thickness } \\
\text { mm }\end{array}$ & $\begin{array}{l}\text { Load } \\
\text { value kN }\end{array}$ \\
\hline 1 & 320 & 579 & 5 & 284.57 \\
\hline 2 & 325 & 653 & 7.5 & 353.65 \\
\hline 3 & 164 & 338 & 3 & 137 \\
\hline 4 & 310 & 1200 & 5 & 97.3 \\
\hline
\end{tabular}

Table .4 comparison between Load Values

\begin{tabular}{|l|l|l|}
\hline Diameter $\mathrm{mm}$ & Experimental $\mathrm{kN}$ & Analytical $\mathrm{kN}$ \\
\hline 320 & 312 & 284.57 \\
\hline 325 & 336 & 353.65 \\
\hline 164 & 124 & 137 \\
\hline 310 & 105.6 & 97.3 \\
\hline
\end{tabular}

The results obtained from the experimental and analytical studies are distinct values.

\subsection{Parametric study}

This includes the parametric study of $\mathrm{D} / \mathrm{t}$ ratio and $\mathrm{L} / \mathrm{D}$ ratio.

i)Five specimen of constant $\mathrm{D} / \mathrm{t}$ ratio and length is varied. The Diameter and thickness of the specimen is kept constant and the length is increased.

From the analysis it is found that the load gets decreased for the increase in length.

Table 5. Load value for varying $L / D$ ratio

\begin{tabular}{|l|l|l|l|l|l|}
\hline $\begin{array}{l}\text { S1. } \\
\text { no }\end{array}$ & $\begin{array}{l}\text { Length } \\
(\mathrm{mm})\end{array}$ & $\begin{array}{l}\text { Diameter } \\
(\mathrm{mm})\end{array}$ & $\begin{array}{l}\text { Thickness } \\
(\mathrm{mm})\end{array}$ & $\begin{array}{l}\text { D/t } \\
\text { ratio }\end{array}$ & $\begin{array}{l}\text { Load } \\
\mathrm{kN}\end{array}$ \\
\hline 1 & 1200 & 152 & 2.65 & 57.3 & 185 \\
\hline 2 & 1500 & 152 & 2.65 & 57.3 & 118 \\
\hline 3 & 1800 & 152 & 2.65 & 57.3 & 82.2 \\
\hline 4 & 2100 & 152 & 2.65 & 57.3 & 60 \\
\hline 5 & 2400 & 152 & 2.65 & 57.3 & 46.27 \\
\hline
\end{tabular}

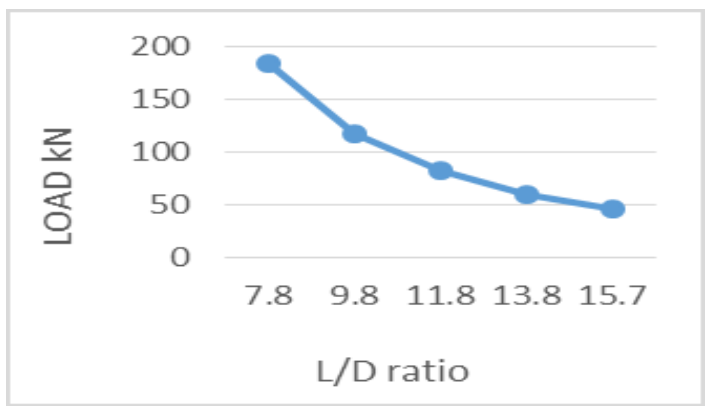

Figure 8. Load vs L/D ratio

ii) Five specimens with an external diameter $152 \mathrm{~mm}$ and the length $3600 \mathrm{~mm}$ of various thickness is analysed in numerical method. Orthotropic properties were used. The Diameter and length of the specimen (L/D) is kept constant and the 
thickness is varied. From the analysis it is found that the load gets increased for the increase in thickness.

Table 6 .Load value for varying $D / t$ ratio

\begin{tabular}{|l|l|l|l|l|l|}
\hline $\begin{array}{l}\text { S1. } \\
\text { no }\end{array}$ & $\begin{array}{l}\text { Length } \\
(\mathrm{mm})\end{array}$ & $\begin{array}{l}\text { Diameter } \\
(\mathrm{mm})\end{array}$ & $\begin{array}{l}\text { Thickness } \\
(\mathrm{mm})\end{array}$ & $\begin{array}{l}\text { L/D } \\
\text { ratio }\end{array}$ & $\begin{array}{l}\text { Load } \\
\text { kN }\end{array}$ \\
\hline 1 & 3600 & 152 & 4.65 & 23.6 & 36.0 \\
\hline 2 & 3600 & 152 & 6.65 & 23.6 & 51.6 \\
\hline 3 & 3600 & 152 & 8.65 & 23.6 & 67.4 \\
\hline 4 & 3600 & 152 & 10.65 & 23.6 & 82.66 \\
\hline 5 & 3600 & 152 & 12.65 & 23.6 & 103.1 \\
\hline
\end{tabular}

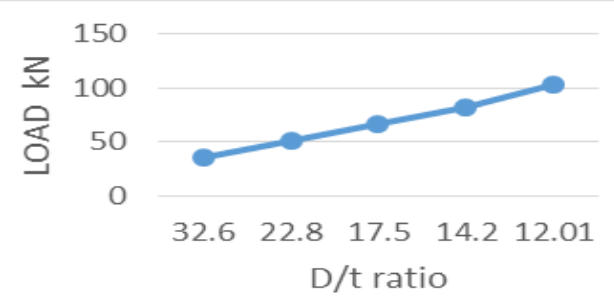

Figure 9. Load vs D/t ratio

\subsection{Stacking sequence}

The stacking sequence plays a crucial role in compressive strength of the GFRP tube. In this the stacking sequence for 14, 19, 25 layers are processed. The stacking sequence for 19 layers is shown in fig.

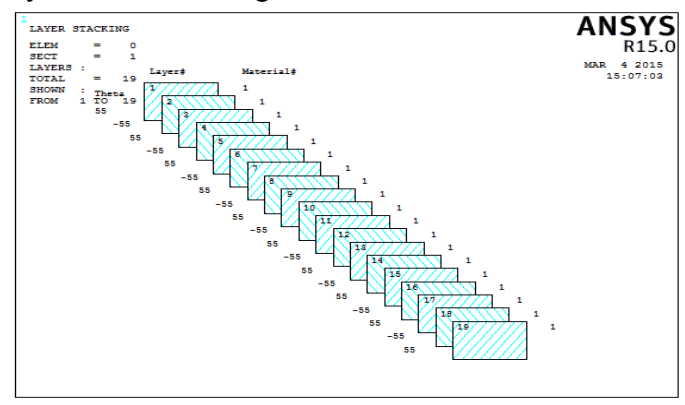

Figure 10. Stacking Sequence for 19 layers

Angle ply laminates which is having plies of same material and thickness is oriented only in $+\theta$ and $-\theta$ are used. Example for angle ply laminate is [19/-19/19/-19]

\subsection{Stresses and deformation of gfrp tube of} 14 layers

In ANSYS the GFRP tube oriented with the angle of $45^{\circ}$, $55^{\circ}, 65^{\circ}, 75^{\circ}, 85^{\circ}$ is analysed using shell 281 element. The stresses and deformations are observed. The angle at which the maximum stress occur is the best angle for the fiber orientation. It gives more strength.

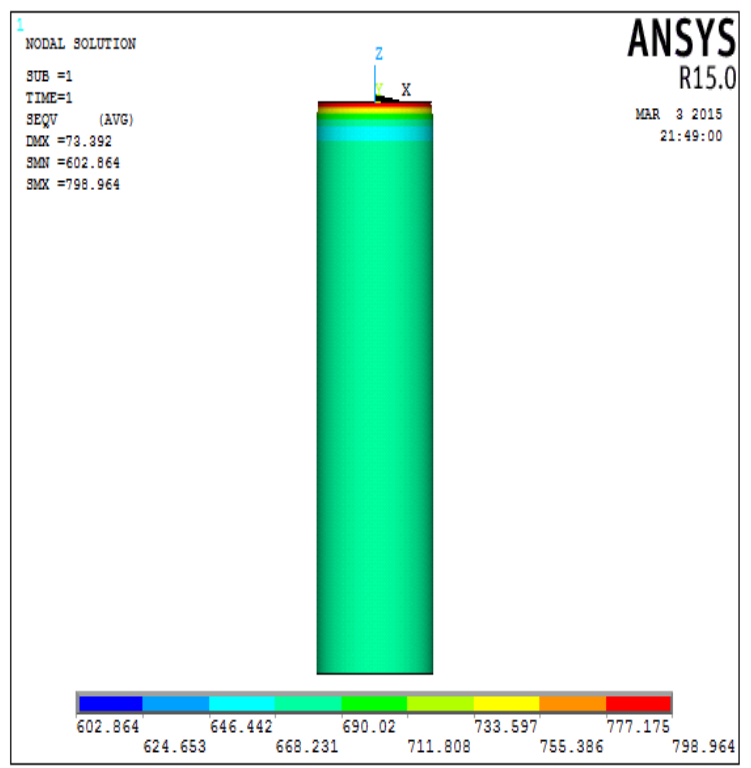

a) $45^{\circ}$ orientation

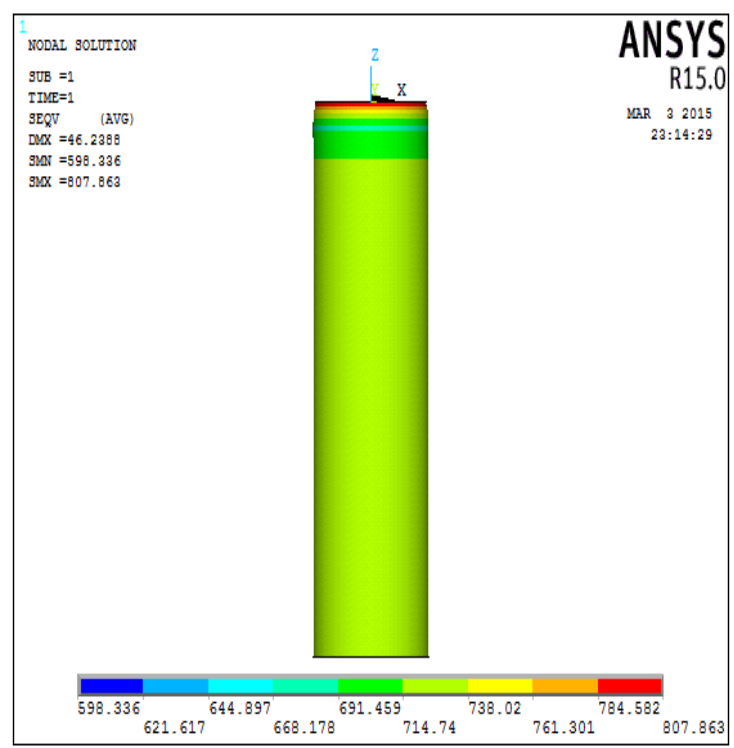

b) $55^{\circ}$ orientation 


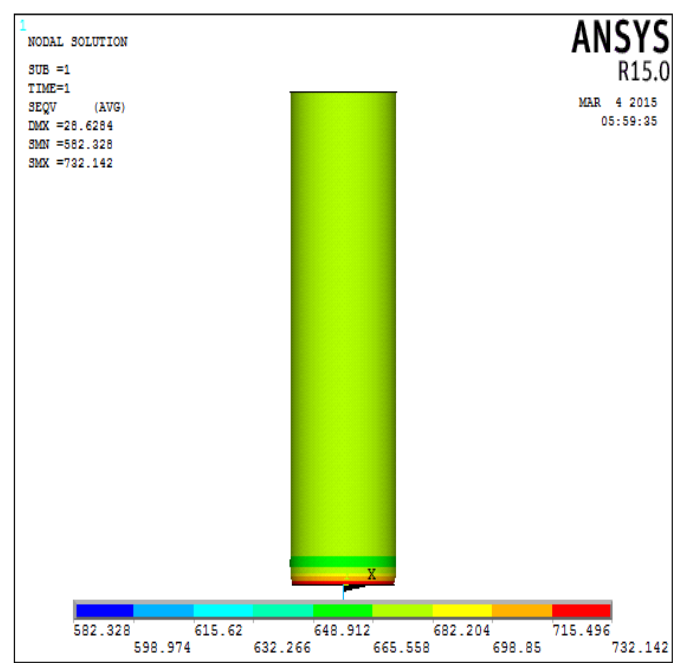

C) $65^{\circ}$ orientation

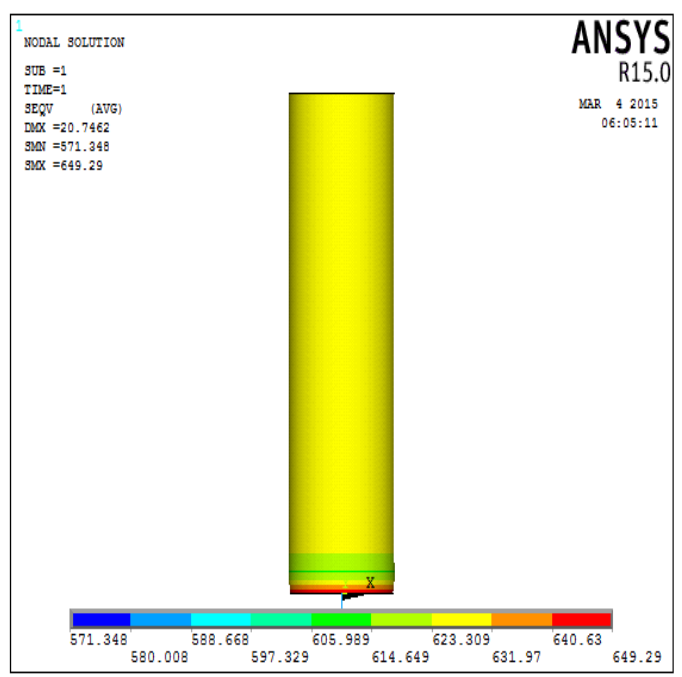

d) $75^{\circ}$ orientation

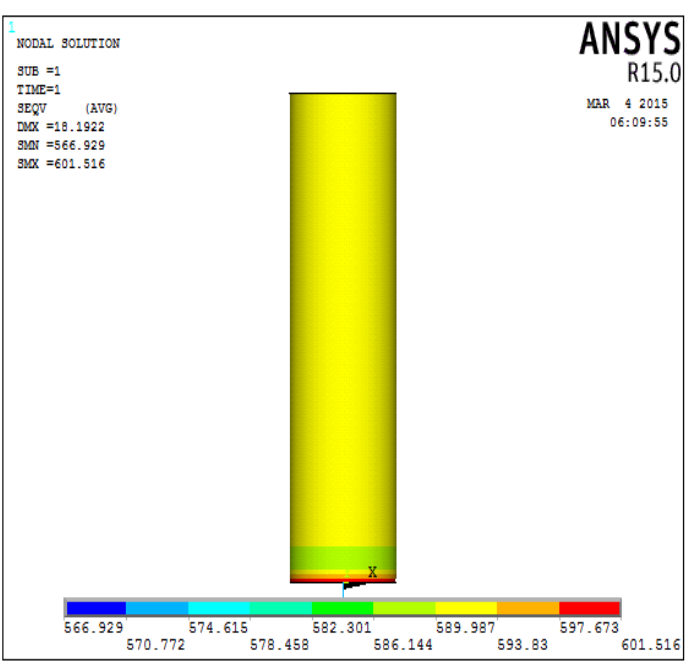

e) $85^{\circ}$ orientation
Table7. Stress And Deformation For 14 layers

\begin{tabular}{|l|l|l|l|l|l|}
\hline Orientation $\left(\theta^{\circ}\right)$ & $45^{\circ}$ & $55^{\circ}$ & $65^{\circ}$ & $75^{\circ}$ & $85^{\circ}$ \\
\hline $\begin{array}{l}\text { Deformation } \\
(\mathrm{mm})\end{array}$ & 73.3 & 46.2 & 28.62 & 20.74 & 18.19 \\
\hline Stress $\mathrm{N} / \mathrm{mm}^{2}$ & 798.3 & 807.8 & 732.1 & 649.29 & 601.5 \\
\hline
\end{tabular}

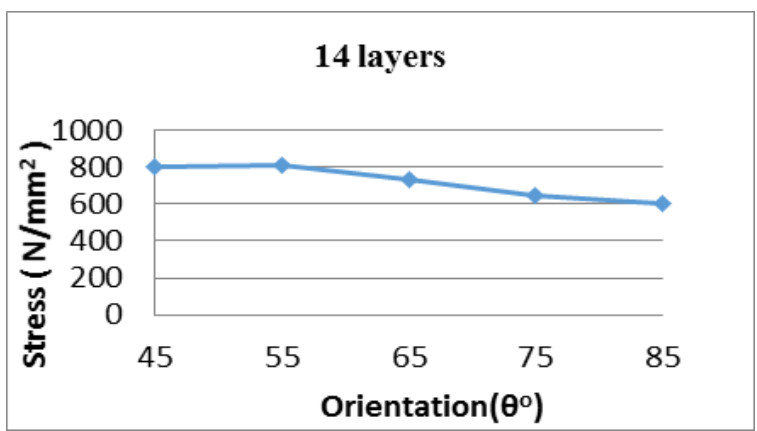

Figure 11. Stress vs orientation (14 layers)

\subsection{Stresses and deformation of GFRP tube of 19 layers}

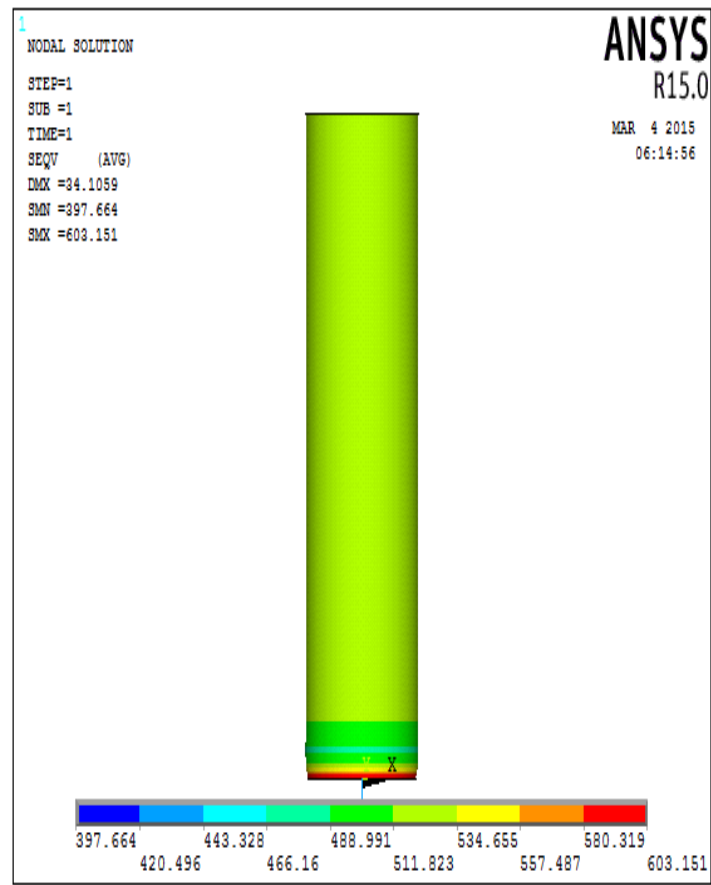

a) $45^{\circ}$ orientation 


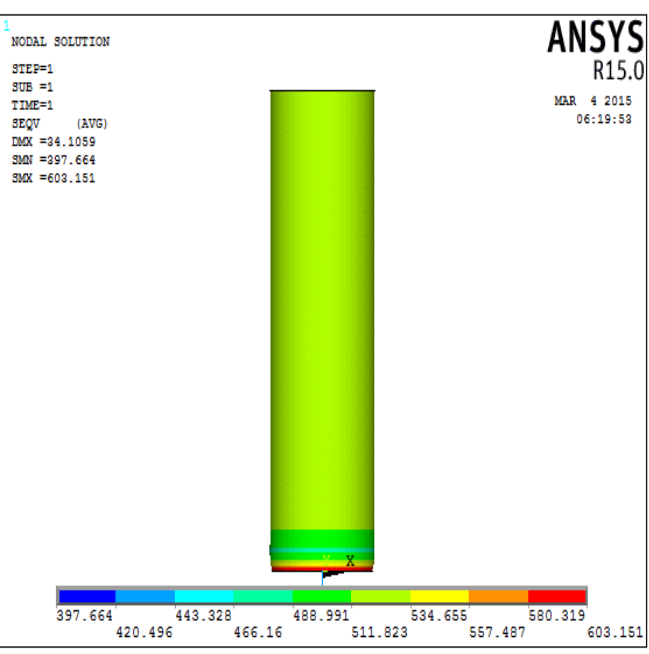

b) $55^{\circ}$ orientation

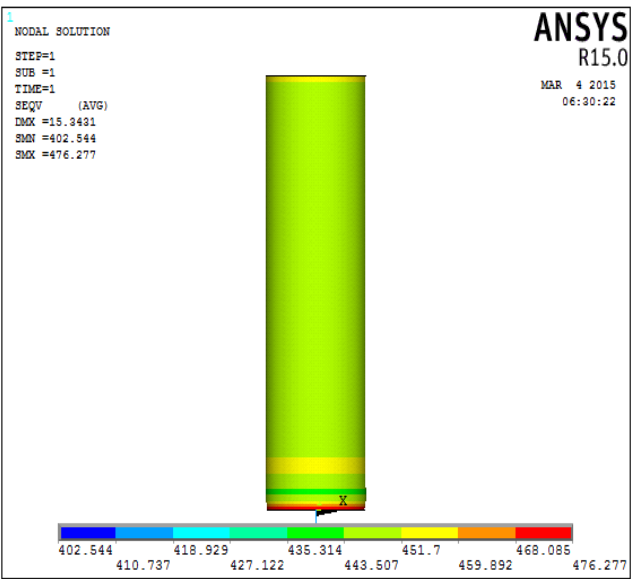

C) $65^{\circ}$ orientation

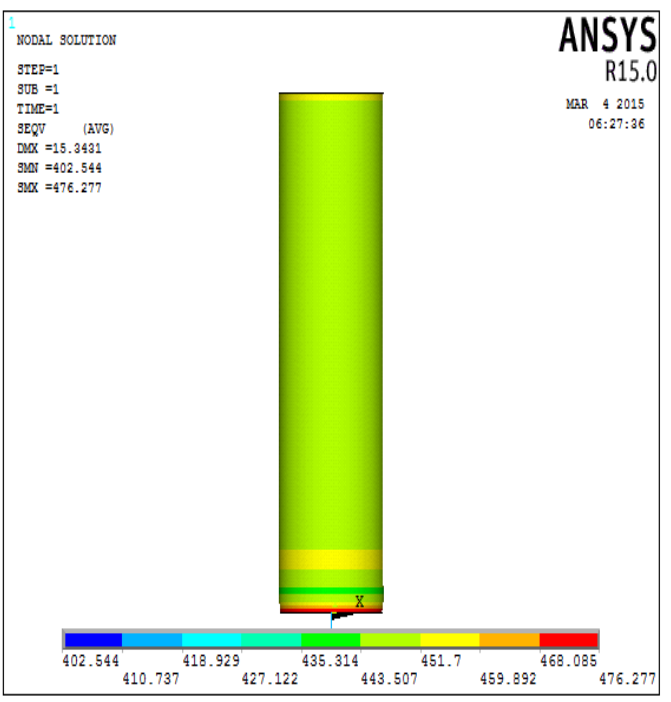

d) $75^{\circ}$ orientation

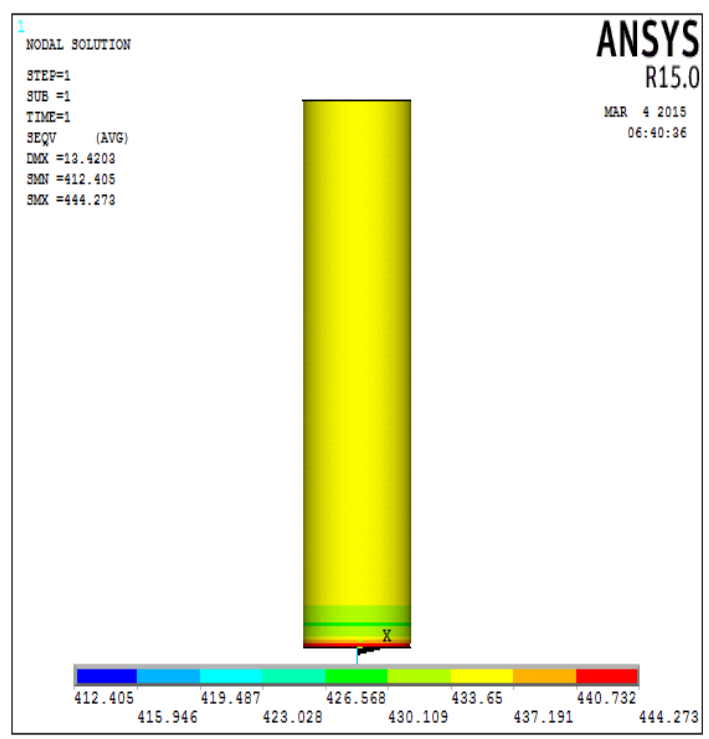

e) $85^{\circ}$ orientation

Table 8.Stress And Deformation For 19 Layers

\begin{tabular}{|l|l|l|l|l|l|}
\hline Orientation $\left(8^{\circ}\right)$ & $45^{\circ}$ & $55^{\circ}$ & $65^{\circ}$ & $75^{\circ}$ & $85^{\circ}$ \\
\hline $\begin{array}{l}\text { Deformation } \\
\text { mm }\end{array}$ & 34 & 34.1 & 15.34 & 15.3 & 13.42 \\
\hline Stress $\mathrm{N} / \mathrm{mm}^{2}$ & 603 & 603.1 & 476.2 & 476 & 444.2 \\
\hline
\end{tabular}

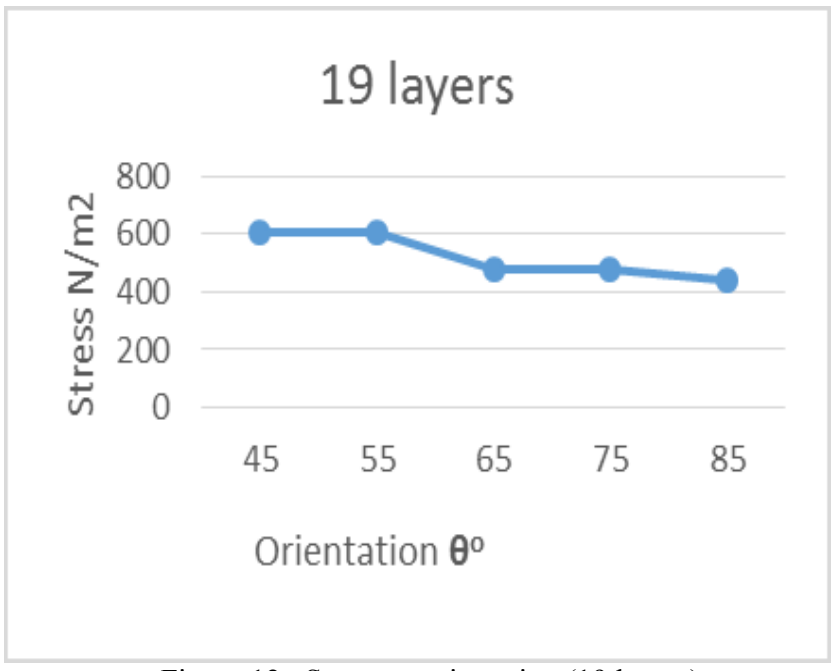

Figure 12 . Stress vs orientation (19 layers) 


\subsection{Stresses and deformation of GFRP tube of 25 layers}

Similarly the stresses and deformation of GFRP tube of 25 layers are obtained using ANSYS.

\section{Table 9 . Stress And Deformation For 25 layers}

\begin{tabular}{|l|l|l|l|l|l|}
\hline Orientation( $\left(\theta^{\circ}\right)$ & $45^{\circ}$ & $55^{\circ}$ & $65^{\circ}$ & $75^{\circ}$ & $85^{\circ}$ \\
\hline Deformation mm & 41.0 & 25.9 & 16.05 & 11.75 & 10.19 \\
\hline Stress N/mm & & & & & \\
\hline & 479 & 481 & 423.9 & 378.8 & 340.06 \\
\hline
\end{tabular}

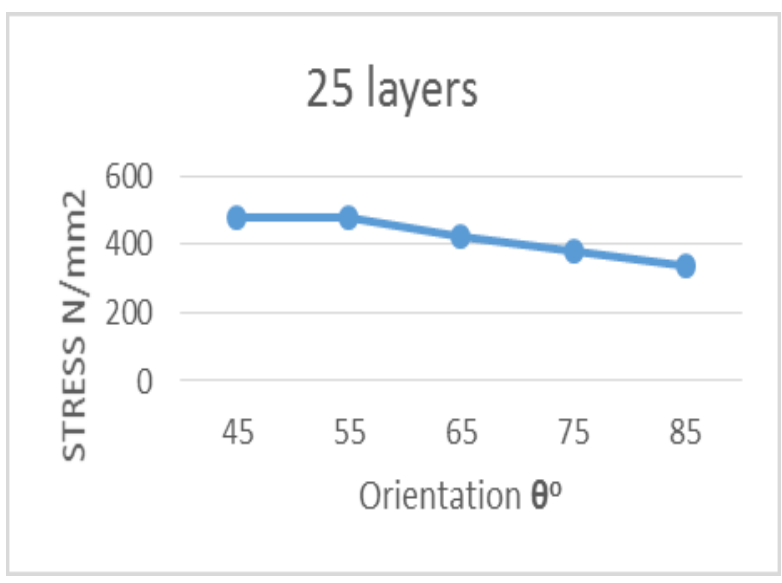

Figure 13. Stress vs orientation (25 layers)

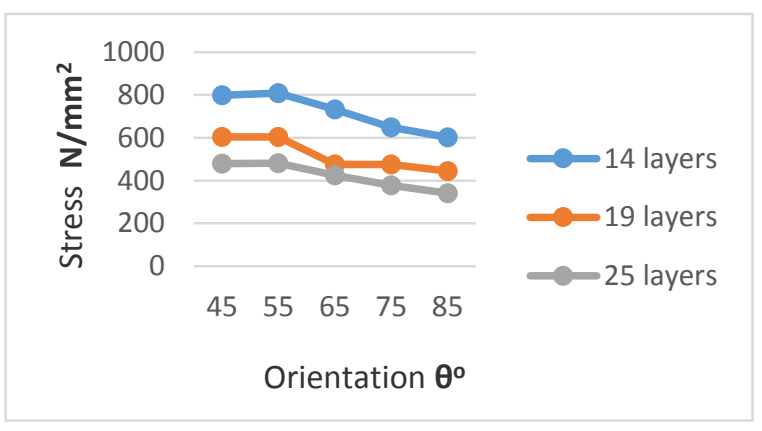

Figure 14. Stress vs orientation (All layers)

\section{CONCLUSION AND REMARKS}

The finite element analyses and experiment works were carried out to examine the compressive behavior of GFRP tubes under axial load. The static and buckling behavior of GFRP tubes were processed. Experimental results were compared with the FEM results. From the experimental work the load obtained is $312 \mathrm{kN}, 336 \mathrm{kN}, 124 \mathrm{kN}, 105.6 \mathrm{kN}$ and for the analytical work the load obtained is $284.57 \mathrm{kN}, 353.65 \mathrm{kN}$, $137 \mathrm{kN}, 97.3 \mathrm{kN}$. The results obtained are similar.

From the parametric study, it is found that the load gets decreased from $185 \mathrm{kN}, 118 \mathrm{kN}, 82.2 \mathrm{kN}, 60 \mathrm{kN}, 46.2 \mathrm{kN}$ by increasing the length from $1200 \mathrm{~mm}, 1500 \mathrm{~mm}, 1800 \mathrm{~mm}$ $1800 \mathrm{~mm}, 2100 \mathrm{~mm}, 2400 \mathrm{~mm}$ and $\mathrm{D} / \mathrm{t}$ is kept constant as $57.4 \mathrm{~mm}$.

By keeping the slenderness ratio as 23.6 constant and by increasing the thickness $4.65 \mathrm{~mm}, 6.65 \mathrm{~mm}$, $8.65 \mathrm{~mm}, 10.65 \mathrm{~mm}, 12.65 \mathrm{~mm}$, the load gets increased from $36 \mathrm{kN}, 51.6 \mathrm{kN}, 67.4 \mathrm{kN}, 82.6 \mathrm{kN}, 103.1 \mathrm{kN}$. Increasing the shell thickness, increases the buckling resistance of GFRP tubes.The compressive strength also gets increased.

The stacking sequence of layer and orientation of fibers plays an important role in compressive strength of GFRP tubes. The orientation of fibers in GFRP tubes in 14, 19, 25 layer of stacking sequence have been studied. The orientation of fibers in $45^{\circ}, 55^{\circ}, 65^{\circ}, 75^{\circ}, 85^{\circ}$ have been considered. In the case of variation of stresses with respect to fiber angle, the angle $55^{\circ}$ gives the maximum stress value which proves the best orientation angle for GFRP tubes. Hence for this angle the compressive strength is more compared to other angle of orientation fibers.

\section{REFERENCES}

[1] J.G. Teng a, T. Yu a, Y.L. Wong a, S.L. Dong b, "Hybrid FRP-concrete-steel tubular columns: Concept and behavior" Construction and Building Materials 21 (2007) 846-854

[2] N. Silvestre "Buckling behaviour of elliptical cylindrical shells and tubes under Compression" International Journal of Solids and Structures 45 (2008) 4427-4447

[3] Kian Karimi , Michael J. Tait, Wael W. El-Dakhakhni "Analytical modeling and axial load design of a novel FRPencased steel-concrete composite column for various slenderness ratios" Engineering Structures 46 (2013) 526-534

[4] N. Silvestre" Generalised beam theory to analyse the buckling behaviour of circular cylindrical shells and tubes" Thin-Walled Structures 45 (2007) 185-198

[5] Daniel C.T. Cardoso a,b,c, Kent A. Harries a, Eduardo de M. Batista b" Compressive strength equation for GFRP square tube columns" Composites: Part B 59 (2014) 1-11

[6] Butje Alfonsius Louk Fanggi, Togay Ozbakkaloglu," Compressive behavior of aramid FRP-HSC-steel double-skin tubular Columns" Construction and Building Materials 48 (2013) 554-565

[7] KentA.Harries a, AndrewJ.Peck a, ElizabethJ.Abraham b, "Enhancing stability of structural steel sections using FRP" Thin-Walled Structures 47 (2009) 1092-1101

[8] Jeffrey Richard Mitchell "Experimental And Numerical Investigations Into Optimal Partial Concrete Filling Of Frp And Steel Tubular Poles" Queen's University Kingston, Ontario, Canada September, 2008

[9] Jianzhuang Xiao, Joan Tresserras, Vivian W.Y. Tam, "GFRP-tube confined RAC under axial and eccentric loading with and without expansive agent" Construction and Building Materials 73 (2014) 575-585 